\title{
SISTEM INFORMASI AKUNTANSI DALAM KAITANNYA DENGAN LAPORAN BIAYA PRODUKSI PADA PERUSAHAAN CV SURYA PRATAMA GEMILANG
}

\author{
Accounting Information Systems In Relation With Production Cost Report On \\ Corporate CV Surya Pratama Gemilang.
}

LUSSAR GERRYCIA GUNAWAN and IRIYADI.

\begin{abstract}
Development of competitive businesses have triggered changes in the various methods of business management to streamline labor costs, overhead costs and raw material costs in improving product quality. Manufacturing companies are in a period of dynamic transformation that requires the manufacturers to always expand its business to survive and have strong competitiveness in addition to the company must have a strategy for its business organization, strategies must be developed by the company in addition to developing the company's products also must develop the data processing. Every company should be able to do if financial data appropriately and accurately to support the company's business decisions. For that a corporate leader needs a tool to control the company, the tool is a useful accounting information system to present the report production costs properly. Hopefully, by the system of all the activities of the company can be run according to plan and to minimize deviations or errors that occur which could harm the company.

Object of research chosen by the authors is the company CV Surya Pratama Gemilang, a medium-sized manufacturing company that produces a variety of bacterial decomposition and laboratory equipment. The company has a systematic record system and computerized production and there are some systems that are still made manually as demand for raw materials from the production to the warehouse with a waffle sometimes only just though the procedure had to use a memo for taking raw materials from the warehouse. In doing production company CV Surya Pratama Gemilang processing raw materials into finished products based on processes that make the production process according to the requirement or determination of the barn, so when the warehouse inventory is less than the policy-setting in the warehouse, the company started production to meet the needs of the provisions in the warehouse. From the nature of the production process suitable production cost calculation is based on the cost method (Process Costing).
\end{abstract}

Keywords: Accounting Information Systems, report production costs, Cost Based Process 


\section{PENDAHULUAN}

Setiap perusahaan baik kecil maupun besar selalu berusaha untuk mempertahankan kelangsungan hidupnya melalui kelancaran operasional perusahaannya. Dalam mempertahankan kelangsungan hidupnya, pimpinan perusahaan dihadapkan pada berbagai masalah diantaranya ketersediaan bahan baku, bahan penolong,biaya tenaga kerja, biaya overhead.

Pengendalian biaya produksi merupakan salah satu fungsi yang sangat penting dalam kegiatan suatu perusahaan manufaktur. Perusahaan manufaktur adalah perusahaan yang mempunyai kegiatan pokok yaitu mengolah bahan baku menjadi produk jadi yang siap untuk dijual, melalui beberapa tahapan yaitu pengadaan bahan baku (procurement), produksi (production), dan penyimpanan produk selesai (warehoushing of finish goods).

Kalkulasi biaya ada dua sistem yang lazim digunakan untuk mengukur biaya yang berhubungan dengan produksi yaitu kalkulasi biaya aktual sistem biaya berdasarkan pesanan (Job Costing) dan sistem biaya berdasarkan proses (process costing) pada dasarnya dua macam sistem penentuan biaya produk yang digunakan dalam jenis industri yang berbeda.

Penentuan biaya berdasarkan pesanan (Job Costing) merupakan sistem penentuan biaya produk yang mengakulasikan dan membebankan biaya kepesanan tertentu. Biasanya digunakan oleh perusahaan yang mempunyai variasi produk atau jasa yang luas/banyak. Departemen produksi pada perusahaan ini melakukan tugas-tugas yang sering kali bervariasi untuk satu produk dengan produk lainnya. Karena setiap produk atau jasa bisa saja membutuhkan operasi yang berbeda-beda, maka cara terbaik untuk menentukan biaya produk atau jasa adalah mengakumulasikan biaya sesuai dengan pesanan atau batch. Sistem biaya berdasarkan pesanan (Job Costing) digunakan jika produk atau jasa khususnya dibuat sesuai dengan kebutuhan pelanggan.

Penentuan biaya berdasarkan proses (Process Costing) mengakumulasikan biaya produk atau jasa berdasarkan proses atau departemen dan kemudian membebankan biaya tersebut ke sejumlah besar produk yang hampir identik. Perusahaan yang secara terus-menerus memproduksi satu atau beberapa produk jasa yang homogen menggunakan sistem penentuan biaya berdasarkan proses (Process Costing). Dalam sistem penentuan biaya berdasarkan proses (Process Costing), biaya produk atau jasa diakumulasikan berdasarkan proses atau departemen dan bukan berdasarkan produk seperti yang dilakukan dalam sistem penentuan biaya berdasarkan pesanan (Job Costing). Biaya produk atau jasa per unit dihitung dengan cara mengakumulasikan biaya proses dan membagi biaya proses total selama periode tertentu dengan unit produk atau jasa yang dihasilkan selama periode tersebut.

semua transaksi siklus produksi yang valid dan sah akan dicatat, semua transaksi siklus produksi dicatat dengan akurat, catatan dipelihara dan dilindungi dari kehilangan, aktivitas siklus produksi dilakukan secara efesien dan efektif.

Hal tersebut tentunya memerlukan sebuah laporan yang disebut sebagai laporan biaya produksi. Tanpa adanya laporan biaya produksi, manajemen tidak dapat melakukan evaluasi secara tepat. Laporan biaya produksi diperlukan untuk mengetahui bagaimana tren biaya yang terjadi pada suatu proses produksi. 
Selain itu juga dapat mengetahui laba atau rugi periodik, menentukan harga jual produk dan juga dapat memantau realisasi biaya produksi.

Dalam hal ini akuntansi menangkap dan mencatat berbagai pengaruh keuangan dari berbagai transaksi perusahaan. Ini meliputi berbagai kegiatan seperti pembelian bahan baku, biaya tenaga kerja langsung, serta biaya overhead pabrik. Untuk menangani transaksi dan proses akuntansi yang rutin terjadi, maka perlu disusun suatu sistem informasi akuntansi.

Setiap perusahaan harus dapat melakukan olah data keuangan secara tepat dan akurat guna menunjang pengambilan keputusan bisnis perusahaan. Sistem informasi diperlukan oleh perusahaan untuk mengolah data menjadi informasi sehingga berbagai pihak yang membuat keputusan dapat menggunakan informasi tersebut untuk membuat keputusan yang baik. Sistem informasi yang baik adalah sistem informasi yang sengaja dirancang oleh perusahaan untuk mengolah data menjadi informasi.

Maka berdasarkan uraian diatas Penelitian ini bertujuan untuk:

1. Untuk mengetahui pelaksanaan sistem informasi akuntansi dalam perusahaan CV. Surya Pratama Gemilang

2. Untuk mengetahui bagaimana pelaporan biaya produksi CV. Surya Pratama Gemilang

3. Untuk mengetahui kaitan sistem informasi akuntansi terhadap pelaporan biaya produksi CV. Surya Pratama Gemilang.

\section{METODE PENELITIAN}

1. Studi kepustakaan (Library Research)

2. Pengamatan (Observasi)

3. Wawancara (Interview)

\section{HASIL DAN PEMBAHASAN}

Dalam melakukan produksinya Perusahaan Surya Pratama Gemilang mengolah bahan baku menjadi produk jadi berdasarkan proses. Walaupun proses produksinya dilakukan tidak secara terus-menerus hanya memenuhi persediaan yang kurang dari penetapan atas kebijakan perusahaan yang berada di gudang maka perusahaan akan memproduksi untuk memenuhi persediaan tersebut. Dan pada prakteknya perusahaan menerima produk berdasarkan pesanan karena berbagai variasi produk yang diproduksi oleh perusahaan, dan perbedaan pesanan dari pelanggan satu dengan pelanggan lainnya sehingga banyak permintaan yang harus dipenuhi perusahaan. Dari sifat tersebut dapat disimpulkan peruhaan CV Surya Pratama Gemilang dalam memperhitungkan biaya produksinya menggunakan biaya produksi berdasarkan proses (Procces Costing), diluar kebijakan perusahaan lainnya.

Beberapa prosedur perusahaan CV Surya Pratama Gemilang dalam menjalankan usahanya :

1. Bagian logistik meninjau dahulu bagaimana persediaan barang jadi yang dimiliki, apakah sudah melewati batas minimal dan dapat memenuhi kebutuhan pelanggan/konsumen atau tidak.

2. Jika bagian logistik mengkonfirmasi bahwa persediaan barang jadi yang tersedia di gudang telah melewati batas minimal yang telah ditetapkan 
perusahaan, maka bagian logistik akan memberitahukan hal tersebut kepada bagian produksi.

3. Bagian produksi yang terdiri dari Chemist dan Microbiology Dept selanjutnya akan mulai mempersiapkan bahan-bahan yang akan dipakai dalam proses produksi. Seperti menyusun rencana dan jadwal produksi dan juga menyiapkan raw material atau bahan baku produksi. Jadwal produksi yang dibuat cukup terperinci dan akurat. Selanjutnya jadwal produksi tersebut dikomunikasikan secara efektif kepada semua bagian produksi untuk dipatuhi dan dilaksanakan.

4. Jika semua bahan baku, tenaga kerja dan peralatan yang terkait proses produksi sudah lengkap dan siap digunakan, maka selanjutnya akan masuk pada proses produksi.

5. Dalam pelaksanaannya, proses produksi harus mempunyai acuan standar yang dapat mengontrol berjalannya proses produksi tersebut. Pada tahap ini, proses produksi selalu mengacu pada Standard Operating Procedure (SOP) yang telah ditetapkan perusahaan untuk mengontrol segala aktivitasnya, dan juga dilakukan Quality Control (QC) untuk memeriksa produk setengah jadi.

6. Setelah proses produksi sampai pada menghasilkan produk jadi, maka perusahaan juga melakukan Quality Control (QC) untuk memeriksa kembali hasil produk jadi yang telah dihasilkan selama proses produksi.

7. Selanjutnya setelah hasil pemeriksaan selesai dan disetujui oleh bagian yang melakukan Quality Control (QC) tersebut, maka produk jadi disimpan di gudang logistik sebagai persediaan dan siap untuk dijual ke konsumen.

Berikut adalah beberapa tahapan dan proses sebelum akhirnya bahan baku diolah menjadi produk jadi penulis sengaja tidak memberikan gambaran tentang bahan baku karena data atau bahan yang diberikan banyak perbedaan antara laporan biaya produksi dan data prosedur selain itu bahan-bahan yang digunakan merupakan rahasia perusahaan yang tidak boleh disebarluaskan dalam pembuatan produk MP tersebut. Berikut adalah proses produksi produk MP :

a. Siapkan air (air khusus) sebanyak 156 Liter dimasak sampai mendidih dalam gentong masak

b. Masukkan (TPI) $10,5 \mathrm{Kg}$ diaduk sampai merata

c. Masukkan (TPK) $5,3 \mathrm{Kg}$ diaduk sampai merata

d. Lakukan pemasakan sampai 2 jam dari bahan dimasukkan

e. Dilakukan penyaringan dengan penyaringan standar

f. Bersihkan dan sterilkan gentong masak

g. Hasil saringan dimasukkan kembali ke dalam gentong

h. Dimasak sampai mendidih kembali

i. Masukkan (GL) 3,5 kg larutkan dengan air khusus, (AR) $1,4 \mathrm{Kg}$, (AC) $2,7 \mathrm{Kg}$, (GR) 1,8 Kg (masing-masing bahan dilarutkan secara terpisah terlebih dahulu dengan menggunakan cairan khusus)

j. Dimasak sampai mengental (1 jam pemasakan)

k. Setelah selesai dimasukkan ke dalam kotak kultur secara steril sesuai kebutuhan

I. Ditambahkan bakteri indukan (RT) 3 Liter secara steril

m. Lakukan pengeraman selama 2 hari jangan sampai lebih akan terjadi pembusukan dengan aroma tidak enak

n. Masukkan dalam gentong kultur selama 2 hari

o. Jalankan pompa sesuai waktu yang ditentukan

p. Masukkan (ESS) 0,7 Liter 
q. Lakukan pengecekan populasi (QC) setelah siap dimasukkan wadah

r. Tunggu stabilisasi sampai sempurna selama 1 minggu

s. Barang siap kirim.

Perusahaan CV Surya Pratama Gemilang adalah perusahaan yang erat hubungannya dengan sistem pengawasan produksi karena sebagian besar kegiatan perusahaan ini berada di dalam fungsi produksi, sistem ini terdiri dari jaringan prosedur untuk mengawasi order produksi yang dikeluarkan agar terjadi koordinasi antara kegiatan penyedia bahan baku, fasilitas pabrik dan penyediaan tenaga kerja guna memenuhi order yang diterima dan pemenuhan persediaan di gudang perusahaan CV Surya Pratama Gemilang.

Dari sifat proses produksi penulis memperhitungkan biaya produksi yang terdiri dari biaya bahan baku, biaya tenaga kerja langsung dan biaya overhead baik yang berperilaku variabel maupun tetap. Untuk menghasilkan laporan biaya produksi perusahaan CV Surya Pratama Gemilang perlu mengidentifikasikan dokemen yang digunakan dalam perhitungan biaya berdasarkan proses (Process Costing) dan memahami arus biaya dalam sistem perhitungan biaya berdasarkan proses, menyiapkan jurnal untuk mencatat biaya dalam perhitungan biaya berdasarkan proses, untuk menangani transaksi dan proses akuntansi yang rutin terjadi, maka perlu disusun suatu sistem informasi akuntansi. Sistem informasi akuntansi harus dirancang sedemikian rupa sehingga data dapat diproses secara efisien untuk menyajikan laporan biaya yang baik.

\section{Formulir Permintaan Bahan Baku}

Perusahaan CV Surya Pratama Gemilang menghasilkan berbagai macam jenis bakteri pengurai, selain bahan baku utama perusahaan juga menggunakan bahan baku penolong. Formulir permintaan bahan baku merupakan dokumen sumber yang berisi (1) spesifikasi tipe dan kuantitas bahan yang dikeluarkan dari gudang, dan (2) identifikasi pekerjaan untuk membebankan biaya bahan.

Formulir ini berperan sebagai alat pengendali bahan yang masuk ke dalam produksi dan juga sebagai bahan persediaan yang dicatat oleh akunting dan formulir permintaan bahan di perusahaan CV Surya Pratama Gemilang ditujukan untuk kepala gudang agar mengeluarkan barang yang dibutuhkan. Seharusnya kepala gudang tidak diizinkan untuk mengeluarkan bahan tanpa formulir permintaan bahan yang telah diotorisasi, namun karena perusahaan ini adalah perusahaan Home Industri yang tidak merumitkan sebuah sistem dan prosedur yang ada terkadang bagian produksi meminta barang hanya dengan lewat omongan saja

\section{Kartu Tenaga Kerja}

Biaya tenaga kerja langsung perusahaan CV Surya Pratama Gemilang merupakan pembebanan tenaga kerja yang dapat dengan mudah ditelusuri ke pekerjaan tertentu. Pada umumnya setiap perusahaan menggunakan kartu jam kerja dalam menghitung biaya tenaga kerja langsungnya yaitu upah yang diberikan berdasarkan jumlah jam kerja dikalikan dengan tarif upah per jam atau perhari kerja tergantung kebijakan perusahaan. Jadi jumlah gaji yang dihasilkan setiap orangnya dalam perusahaan CV Surya Pratama Gemilang berdasarkan hari kerjanya dalam membuat produk tertentu atau jam membuat produk tertentu. 


\section{Pembebanan Biaya Overhead}

Selain biaya bahan baku dan tenaga kerja langsung pembebanan biaya overhead pabrik juga perlu diperhitungkan untuk memperhitungkan biaya-biaya perusahaan dalam proses produksinya untuk memerinci jumlah biaya yang dikeluarkan untuk suatu produk produksi

\section{Laporan Biaya Produksi}

Dengan demikian berdasarkan rincian data=data di atas dapat dibuat kartu biaya yang berisi data bahan baku, tenaga kerja, dan overhead pabrik yang dibebankan ke produk yang diproduksi. Sesudah bahan baku langsung dikeluarkan, biaya bahan baku langsung tersebut dicatat ke dalam kartu biaya tersebut

\section{SIMPULAN}

1. Perusahaan CV Surya Pratama Gemilang adalah perusahaan yang memproduksi bakteri pengurai dan berbagai macam alat laboraturium,tapi penulis hanya menekankan produk bakterinya saja. Proses pengolahan data yang digunakan perusahaan telah terkomputerisasi dengan baik seperti adanya kartu persediaan, adanya kartu tenaga kerja dan formulir permintaan barang ke gudang,bukti penerimaan barang, dan bukti barang keluar pun telah dicatat dengan baik, pengotorisasian dokumen-dokumen pun telah dilaksanakan dengan baik. Serta proses produksi yang dilakukan telah mempunyai standar sendiri oleh bagian QC (Quality Control) terhadap produk tersebut.

2. Sistem dan prosedur yang berkaitan dengan proses produksi berawal dari permintaan dari gudang karena persediaan di gudang kurang dari stock yang ditetapkan perusahaan. Dimana biaya proses produksi ini dibebankan melalui formulir permintaan bahan baku namun terkadang prosedur dalam permintaah bahan tidak menggunakan kartu permintaan bahan baku dan langsung meminta kepada bagian gudang untuk menyiapkan bahan baku karena perusahaan CV Surya Pratama Gemilang termasuk perusahaan Home Industri yang kerap kali prosedur yang diterapkan tidak dimaksimalkan dengan baik, kartu jam tenaga kerja langsung, tarif overhead,biaya-biaya ini diringkas dalam suatu laporan yang dikenal dengan sebagai kartu biaya (Process Cost). Pembuatan sistem informasi akuntansi ini berhubungan dengan proses produksi perusahaan, pencatatan akuntansi sampai pembuatan laporan biaya produksi. 


\section{SARAN}

Perusahaan harus membuat alur proses produksi harus dirancang dengan baik lagi dan alur prosedur harus semaksimal mungkin antara bagian gudang dan produksi harus ada bukti-bukti pengeluaran maupun penerimaan barang dengan baik agar bagian akunting bisa mengimput data dengan persediaan bahan yang real dan mudah untuk mengotorisasinya dan pembuatan Laporan Biaya Produksi lebih disusun dengan baik lagi agar pembaca informasi bisa jelas dan langsung dapat mengerti apa yang terkandung dalam laporan tersebut dan alur serta penyajiannya pun harus jelas dan lebih rapih lagi, karena walaupun perusahaan merupakan sebuah Home Industry yang mempunyai sistem tidak terlalu rumit dan tidak terlalu menyeluruh tetapi kerapihan dan kejelasan sebuah Laporan Biaya Produksi itu sangatlah mendasar dan penting.

\section{DAFTAR PUSTAKA}

Assauri, Sopian. 2004. Manajemen Produksi dan Operasi. Edisi 4, Jakarta

Bodnar, George H. \& William S. Hopwood. 2003. Sistem informasi Akuntansi, Edisi 8. Alih bahasa: Deddy Jacobus, Gramedia, Jakarta

Carter, Wiliam K dan Milton F. Usry. 2006. Akuntansi Biaya, Edisi Ketigabelas, Buku I,Penerbit Salemba Empat, Jakarta.

Crushing Barryl., Marshall B. Romney. 2004. Accounting Information System. $6^{\text {th }}$ Edition, Addison-Wesley, USA

Dadan Umar Daihani. 2007. Komputerisasi Pengambilan Keputusan. PT. Elexmedia Komputindo, Jakarta.

Darsono, Prawironegoro. 2005. Akuntasi Manajemen. Diadit Media, Jakarta

Garrison, Ray H. 2002. Managerial accounting. 3th Edition. Reason Education Inc, Upper Saddle River, New Jersey, 07458

Garrison, Ray H, Eric H. Noreen, dan Peter C. Brewer. 2006. Akuntansi Manajerial. Edisi Kesebalas. (Diterjemahkan oleh: Nuri Hinduan dan Edward Tanujaya). Penerbit Salemba Empat, Jakarta

Hall, James. A. 2007. Accounting Information Systems. Edisi 4. Alih bahasa: Dewi Fitrianingsih. Salemba Empat, Jakarta

Hansen dan Mowen. 2005. Management Accounting. Buku 2. Edisi ke 7. Salemba Empat. Jakarta

Hartono Jogiyanto. 2013. Sistem Tekhnologi Informasi Bisnis Pendekatan Strategis, Erlangga, Jakarta.

Horngren, Charles T. dan Srikant M. Datar dan George Foster. 2006. Akuntansi

Biaya. Edisi Keduabelas. Penerbit Erlangga, Jakarta

Johar Arifin. 2008. Komputer Akuntansi,PT. Elexmedia Komputindo, Jakarta 
Joseph W. Wilkinson. 2004. Accounting and Information Systems. John Wiley \& Sons, Inc. Canada.

Laudon, Kenneth C dan, Jane P. 2004. Manajement Information Systems : Managing The Digital Firm. Prentice Hall Inc, New Jersey

Michell Suharli. 2006. Akuntansi Untuk Bisnis Jasa Dan Dagang, Yogyakarta: Graham IImu

Moh Ramli Faud dan M. Rustan D.M. 2005. Akuntansi Perbankan, Cetakan Pertama, Graha Ilmu, Yogyakarta

Mubarak, M.M. and Syarif, R., 2006. Dampak Pelatihan Kerja Terhadap Kualitas Kerja Karyawan. Jurnal IImiah Kesatuan Nomor, 8(20), p.2.

Mulyadi. 2006. Akuntansi Biaya. Edisi 5, Akademi Manajemen Perusahaan, Yogyakarta

Mulyadi, 2008. Sistem Akuntansi, Salemba Empat, Jakarta

Riwadi. A. Supriyono. 2006. Akuntansi Biaya. BPFE, Yogyakarta

Romney, Marshall B. dan Paul John Steinbart. 2006. Accounting Information System. Alih bahasa : Dewi Fitrianingsih. Salemba Empat, Jakarta

Soemarso. 2005. Revisi Akuntansi Suatu Pengantar. Buku 1. Edisi 5, Salemba Utama, Jakarta

Sabarguna, Boy S. 2005. Sistem Informasi Akuntansi Rumah Sakit. Penerbit Konsorsium Rumah Sakit Islam Jateng - DIY

Sanyoto Gondodiyoto. 2007. Audit Sistem Informasi, Mita Wacana Media, Jakarta.

Sofyan Syafri Harahap, Drs., MS Ac. 2003. Teori Akuntansi. Edisi Revisi. Cetakan Keenam.Jakarta: PT. Raja Grafindo Persada

Sugiri Munawir. 2002. Akuntansi Keuangan dan Manajemen. Edisi 1, BEF, Yogyakarta

Suhayati, Ely dan Sri Dewi Anggadini, Pengantar Akuntansi l, Bandung, 2005

Suryadi Prawirosentono, 2007. Manajemen Operasi. Edisi 4. Bumi Aksara, Jakarta

Sutabri,Tata. 2004. Sistem Informasi Akuntansi, Yogyakarta : Andi

Szymanski, Robert A. 2005. Computer and Information Systems. Alih bahasa : Deny Arnos. Salemba Empat, Jakarta

Wing Wahyu Winarno, 2004. Sistem informasi manajemen, UP AMP YKPN, Yogyakarta 